\title{
Authors' Instructions: Analysis of Fire Extinguishing Services Based on Disaster Mitigation at the Fire and Safety Department of Banda Aceh
}

\author{
Nazarul Saddam ${ }^{1}$ Indra $^{2}$ and Alamsyah Taher ${ }^{3}$ \\ ${ }^{1}$ Magister of Disaster Science. University of Syiah Kuala, Jalan Hamzah Fansuri No 4, \\ Darussalam, Banda Aceh, Indonesia \\ ${ }^{2}$ Faculty of Agriculture, University of Syiah Kuala, Darussalam, Banda Aceh, Indonesia \\ ${ }^{3}$ Faculty of Teacher Training and Education, University of Syiah Kuala Darussalam, Banda \\ Aceh \\ Darussalam, Banda Aceh, Indonesia \\ \{nazarulsaddam@yahoo.com,indra_ipb@yahoo.com,alamsyah@unsyiah.ac.id\}
}

\begin{abstract}
Fire and Safety Department is a government agency that specifically handles fire prevention. Fires can result in material losses and have a high potential for death, thus requiring attention to the safety of residents of residential areas. This certainly requires an organization/agency that provides good and optimal service to obtain success, especially in the Fire and Safety of Banda Aceh. This study aims to analyze the service system of the Fire and Safety Department of Banda Aceh to the community and develop alternative strategies to improve the provision of fire services to the community. The data used in this study are primary data and secondary data. The primary data is obtained from observation, interviews, and distribution of questionnaires. The secondary data obtained through books, journals, and the Central Bureau of Statistics of Banda Aceh. Respondents in this study were 47 people. This study uses a qualitative descriptive method and SWOT analysis (Strengths, Weaknesses, Opportunities, Threats). The results of the study show that the Fire Service and Service System of the Fire and Safety Department of Banda Aceh are currently quite good. The administration system in accordance with the SOP, facilities, and infrastructure that have begun to be adequate in handling, and have good teams and management. Only in terms of facilities and infrastructure that are still lacking in regular maintenance, thus making the firefighter team's performance less than optimal. One of which is the 18 hydrant points in Banda Aceh, only 14 points are functioning properly. The results of the SWOT analysis show that the strategy needed is a growth strategy obtained from the meeting of the two axis points that lead to the $\mathrm{V}$ quadrant. Therefore, there are five strategies using the SWOT analysis, such as increasing mitigation efforts with a program of periodic maintenance on facilities and infrastructure so that it will be ready to use at any time and improve employee performance with socialization programs to improve knowledge and skills in handling fire cases.
\end{abstract}

Keywords: Service, Mitigation, Strategy.

\section{Introduction}

Fire is one of the most frequent disasters. Hot and dry weather with excessive sunburn, human conditions, and habits in the use of machinery, technology, and tools improperly: cultivating arable land carelessly: factory use that does not refer to security and the application of improper fire prevention often causes fire disasters. This includes almost all parts of the social 
order and government and other special arrangements such as small to large scale companies or factories [1].

Fire Department is a government agency that specifically handles fire prevention. The main purpose is to be able to overcome, prevent and cope with fire incidents in Banda Aceh. The implementation of the tasks carried out by the Fire and Safety Department of Banda Aceh has not run smoothly as expected by the community. This can be seen from the lack of socialization to the public about the dangers of fire and the limitations of facilities and infrastructure to reach dense residential areas so that the efforts to prevent and help fire suppression cannot be carried out properly.

Based on information from the daily newspaper Serambi, at the end of 2015, a fire truck type Firedom feal $33 \mathrm{M}-\mathrm{CMU}$ was shouted by the residents during the process of fire outage of Sinbun Sibreh supermarket. Hundreds of people around were shouted because the water sprayed was only a little. Though the mentioned fire truck is referred to as the most sophisticated fire truck in Indonesia. Although the fire truck that was bought for Rp.16 Billion, its performance like plant sprinkler car and the water available is not much different from the usual fire truck.

The success of work in service delivery cannot be separated from the good performance of the members of the organization, both individual performance, and team performance. The level of organizational performance can be seen from to what extent the organization is able to reach the targets, objectives, vision, and mission have been determined. With the policy of regional autonomy, the government in the district level is required to be able to develop and increase the various potentials through related agencies to improve organizational performance.

A previous study conducted by Adelberty [2] on the quality analysis of the Surabaya Fire Department, explained that the quality of service at Fire Department of Surabaya City based on service quality dimensions, in general, has not been optimally fulfilled. Especially in indicators of officer attitudes, ease of procedure, service according to SOP and service satisfaction get low scores. This incompatibility is not solely from the fire department itself but also influenced by external factors, which are related to lack of public participation and awareness, traffic congestion, incorrect information, hindered by crowds of people watching fire events, and the influence of infrastructure, including difficult access to locations where fires are occurring. Such as a narrow entrance alley, the number of portals, a gate that is not in accordance with standardization, and the number of speed bumps, and the density of buildings in the fire area.

A previous study conducted by Widayanto [3] on the Performance Analysis of Fire Extinguishers in Fire Fighting Efforts at the Fire Department of Semarang City, explained that the results of the classification of service attitudes, human resource qualifications, education, and training were still weak. This is based on the results of the study which each indicator gets an average score below $60 \%$.

From the description and previous study that have been explained, this study aims to analyze the system of providing fire services at the Fire and Safety Department in Banda Aceh and develop an alternative strategy to improve the delivery of fire services and safety in Banda Aceh.

\section{Methods}

This research was conducted directly at the Fire and Safety Department of Banda Aceh. Address at Jalan Soekarno-Hatta No. 53, Gampong Geuceu Meunara, Jaya Baru Sub-District, Banda Aceh. The method used in this study is descriptive which was a method aimed at describing existing phenomena. 
The population in this study were all employees at the Fire and Safety Department of Banda Aceh, which numbered 87 people. Samples will be selected using the Simple Random Sampling method or random sample [4]. Slovin formula used to determine the total number of samples [5]. The total samples were 50 people, that were 47 respondents from the employees of Fire and Safety Department of Banda Aceh and 2 respondents from the community based on their experience served by the Fire and Safety Department of Banda Aceh, and a key witness when the fire occurred in Banda Aceh to get more detailed information about the service of the Fire and Safety Department of Banda Aceh.

The data collected through several steps. The first step was an observation to directly see the availability of facilities and infrastructures owned by Fire and Safety Department of Banda Aceh in serving the community. The second was by distributing questionnaires to obtain detailed information about the services in serving the community. The last step was deep interview and documentation relating to the availability of facilities and infrastructure that support the service system. In the process of data processing the steps that must be taken are editing, coding, data entry, and data cleaning.

Then, the data will be analyzed using a SWOT analysis (Strengths, Weaknesses, Opportunities, and Threats) to design a RENSTRA (Plan and Strategy) service to improve the service of the Fire and Safety Department of Banda Aceh to the community. Service planning is a dynamic, continuous process, including the process of formulating a problem and the process of implementing a predetermined plan followed by an evaluation. The results of this SWOT analysis will direct the results of this study on the formation of strategic planning. Planning this strategy is a more detailed elaboration into a medium-term work plan in order to implement what has been formulated.

\section{Discussion}

The main task of the Fire and Safety Department of Banda Aceh is to carry out the government affairs in preventing, responding emergency, preventing fire and rescuing. Because of the working area of the Fire and Safety Department of Banda Aceh is adjacent to the working area of the Fire and Safety Department of Aceh Besar, the Fire and Safety Department of Banda Aceh expanded its work area to $10 \mathrm{KM}$ farther from Banda Aceh to assist the work of the Fire and Safety Agency of Aceh Besar. Before carrying out the deployment of personnel and fleet assistance, firstly the coordination between leaders must be carried out. The task of Fire and Safety Department includes formulating fire and rescue policies, providing support for the implementation of regional government in the field of fire and rescue, fostering and mentoring agencies in their work areas in order to respond to fire disasters and to rescue if it occurs, until evaluations and reports related to the fire sector and rescue.

\subsection{Service System}

In carrying out its duties, the non-structural assets such as a post or a guarding place for Fire and Safety Department of Banda Aceh have 5 post points, namely:

1. Headquarter, located in Geuceu KotaBanda Aceh

2. Auxiliary Unit Post, located in Pango, Banda Aceh

3. Auxiliary Unit Post, located in Jeulingke, Simpang Mesra, Banda Aceh

4. Auxiliary Unit Post, located in Gampong Mulia, Banda Aceh

5. Auxiliary Unit Post, located in Keudah, Banda Aceh 
To carry out the main tasks and functions of the organization, the currently available resources are 9 units of fire extinguisher cars, 1 unit of a ladder fire engine and 3 units of supply cars. To support the easy running of the fire problem, the Fire and Safety Department of Banda Aceh also has hydrants spread over 18 points in Banda Aceh. Out of 18 hydrant points scattered in Banda Aceh, only 14 hydrants work properly, the remaining 4 are damage.

In terms of the quality of service for the officers of the Fire and Safety Department of Banda Aceh, all of the 47 of the officers surveyed claimed to have provided maximum service to the community according to the SOPs that apply in the department. For example from the indicators of the ability and attitude of the officers to the community, and also the ease of procedures given by the Fire and Safety Department officers to the community in accordance to the SOP. The community only needs to call $0651-44123 / 133$, and the officers will immediately arrive at the location. Nevertheless, the firefighters often get a bad response from the panicked communities. Furthermore, the employees of the Fire and Saftey Department claimed that they got a fake phone call several times so that when the Firefighters arrived at the location, there was no fire occurred. For this reason, the respondent from the department hoped that there would be a special policy or punishment from the Government towards the people who made false reports so that this incident would not happen again in the future. Because this is very detrimental to the Fire and Safety Department officers, especially the Fire and Saftey Department of Banda Aceh.

The results of this study are the same as the previous study conducted by Vendri[6]. In his research on Strategies for Improving the Service of Fire and Safety Department of Province of DKI Jakarta, there were many obstacles faced by the firefighter in serving the community. For example, facilities that had begun to be damaged so the officers could not work optimally, and so many ignorant people tried to fake call to the department. For this reason, a special budget slot is needed for the maintenance of facilities and legal policies for the people who violate these rules.

\subsection{Alternatives Strategy}

From the results of the study that has been done. Starting from the observation, distribution of questionnaires and interviews, the internal and external key factors (IFAS and EFAS) which are important in the analysis of services at the Fire and Saftey Department of Banda Aceh along with weight values and ratings can be seen in table 1 below.

\begin{tabular}{lccc}
\hline \multicolumn{4}{c}{ Table 1: Internal Factor Analysis Summary (IFAS) } \\
\hline Internal Factors & Weight & Rating & $\begin{array}{c}\text { Weighted } \\
\text { Value }\end{array}$ \\
\hline STRENGTHS & 0,07 & 2 & 0,14 \\
\hline Have 5 post and 1 headquarter & 0,08 & 2 & 0,16 \\
\hline Have had 3 types of fire engine & & & \\
\hline $\begin{array}{l}\text { Have collaborated with PDAM } \\
\text { (Indonesian Water Utility Company) for } \\
\text { the water supply other than water that } \\
\text { obtained directly from nature }\end{array}$ & 0,12 & 3 & 0,36 \\
\hline Have had 18 Hydrant & 0,16 & 3 & 0,48 \\
\hline $\begin{array}{l}\text { Have had 1 phone number that easy to } \\
\text { remember by the community }\end{array}$ & 0,09 & 3 & 0,27 \\
\hline SUB TOTAL & 0,52 & & 1,41 \\
\hline WEAKNESSES & & & \\
\hline
\end{tabular}




\begin{tabular}{llll}
\hline $\begin{array}{l}\text { Judging from the SOP of Fire and Safety } \\
\text { Department service, the number of fire } \\
\text { engine units is still lacking }\end{array}$ & 0,07 & 2 & 0,14 \\
$\begin{array}{l}\text { Do no't have a smaller fire engine to reach } \\
\text { narrow roads }\end{array}$ & 0,08 & 2 & 0,16 \\
\hline $\begin{array}{l}\text { PDAM (Indonesian Water Utility } \\
\text { Company) water pressure is not strong }\end{array}$ & 0,10 & 3 & 0,30 \\
\hline $\begin{array}{l}\text { Out of 18 hydrant point, only 14 points } \\
\text { work }\end{array}$ & 0,11 & 3 & 0,33 \\
\hline $\begin{array}{l}\text { Telephone numbers for emergency calls } \\
\text { are charged }\end{array}$ & 0,12 & 3 & 0,36 \\
\hline$\quad$ SUB TOTAL & $\mathbf{0 , 4 8}$ & & $\mathbf{1 , 2 9}$ \\
\hline TOTAL & $\mathbf{1 , 0 0}$ & $\mathbf{2 , 7}$ \\
\hline
\end{tabular}

Source: primary data (modified), 2019

From table 1, the maximum possible value is four which identifies maximum strength without any weakness in the service factor of the department. The lowest value is zero, which means that these factors are a full weakness without the slightest strength in the service factor of the Fire and Safety Department of Banda Aceh. The numbers bigger than 3.0 are included in the high category, values above 2.0 to 2.99 are categorized as a medium, while values between 1 and 1.99 are categorized as low. Then the value-weighted of 2.7 includes the medium category. Next for External Factor Analysis (EFAS) can be seen in table 2.

Table 2: External Factor Analysis Summary (EFAS)

\begin{tabular}{llcc}
\multicolumn{1}{c}{ External Factors } & Weight & Rating & Weighted Value \\
\hline $\begin{array}{l}\text { Cooperation between related agencies in the } \\
\text { city of Banda Aceh has been established }\end{array}$ & 0,10 & 2 & 0,20 \\
\hline $\begin{array}{l}\text { Officers have sufficient skills and abilities } \\
\text { obtained from the selection and get regular } \\
\text { science updates }\end{array}$ & 0,11 & 3 & 0,33 \\
\hline $\begin{array}{l}\text { Fire and Saftey Department get direct } \\
\text { assistance from the local government }\end{array}$ & 0,07 & 3 & 0,21 \\
\hline $\begin{array}{l}\text { The development of knowledge and } \\
\text { technology related to fire outage and rescue } \\
\text { facilities and infrastructure }\end{array}$ & 0,13 & 3 & 0,39 \\
\hline $\begin{array}{l}\text { The location of the post is on the border and } \\
\text { close to the district of Aceh Besar. }\end{array}$ & 0.11 & 1 & 0,11 \\
\hline \multicolumn{1}{c}{ SUB TOTreats } & $\mathbf{0 , 5 2}$ & & $\mathbf{1 , 2 4}$ \\
\hline $\begin{array}{l}\text { There are still people who do not know the } \\
\text { emergency phone number of the Fire and } \\
\text { Safety Department }\end{array}$ & 0,08 & 2 & 0,16 \\
\hline $\begin{array}{l}\text { The community does not yet have the ability } \\
\text { to reduce the risk of fire }\end{array}$ & 0,09 & 3 & 0,27 \\
\hline $\begin{array}{l}\text { The community does not yet have the } \\
\text { awareness to behave in an orderly manner in } \\
\text { the process of evacuation and fire suppression }\end{array}$ & 0,11 & 3 & 0,33 \\
\hline $\begin{array}{l}\text { Lack of budget for repairs to facilities } \\
\quad\end{array}$ & 0,13 & 4 & 0,52
\end{tabular}


Public awareness is still lacking in giving the location of the incident and often deceiving officers

\begin{tabular}{ccc}
\hline SUB TOTAL & 0,48 & 1.49 \\
\hline TOTAL & 1,0 & 2,73
\end{tabular}

Source: primary data (modified), 2019

From table 2 can be seen that the weighted value is 2.73 with the assumption of the community towards the service of the Fire and Safety Department of Banda Aceh has high-tech facilities in dealing with fire disasters but the facilities are poorly maintained. Then the value of 2.73 is included in the medium category means that the firefighters of Fire and Safety Department of Banda Aceh have high skills and knowledge in dealing with fire, coupled with high technology so that the services of the department can improve in the future. The average value of IFE is 2.7 and the average value of the EFE is 2.73, so the total weighted value is 2.72 . The assembly point of these two values is in quadrant V. For more details, see the following table 3 .

Table 3: Matrix IE

\begin{tabular}{|c|c|c|c|}
\hline & $\begin{array}{l}\text { Strong } \\
3,0-4,0\end{array}$ & $\begin{array}{c}\text { Average } \\
2,99 \\
2,9\end{array}$ & $\begin{array}{r}\text { Weak } \\
1-1,99 \\
\end{array}$ \\
\hline $\begin{array}{l}\text { Strong } \\
3,0-4,0\end{array}$ & I & ఏII & III \\
\hline 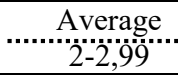 & ...IV. & $\sum^{\mathrm{V}}$ & VI \\
\hline $\begin{array}{l}\text { Weak } \\
1-1,99\end{array}$ & VII & VIII & IX \\
\hline
\end{tabular}

\subsection{Subtitle}

From table 3 can be seen that the assembly point of the two axes is in the cell or the V quadrant. It shows that the strategy needed to strengthen the service of the Fire and Safety Department of Banda Aceh currently is a growth strategy. The growth strategy shows that the service of the Fire and Safety Department of Banda Aceh requires a strategy that can improve or develop the services of the department. The strategy that can be applied to the service of the department is the organizational development strategy by making management improvements. Based on the results of the analysis above, a SWOT matrix was created which contained analysis of strength and opportunity (SO) strategies, analysis of weaknesses and opportunities (WO), strength and threat strategy analysis (ST) and weakness and threat strategy (WT) analysis, for more details. seen in table 4 .

Table 4: SWOT Matrix

\begin{tabular}{|c|c|c|c|}
\hline Strategy S-O & Strategy W-O & Strategy S-T & Strategy W-T \\
\hline $\begin{array}{l}\text { Optimizing organizational } \\
\text { planning and development } \\
\text { by improving management, } \\
\text { placing the human resource } \\
\text { in the right position and } \\
\text { effectiveness of budget use } \\
\text { that is right on the target }\end{array}$ & $\begin{array}{l}\text { Increasing mitigation efforts } \\
\text { by conducting periodic } \\
\text { inspection programs on } \\
\text { building, facilities, and } \\
\text { facilities such as hydrants and } \\
\text { water suppression engine so } \\
\text { that ready to use anytime }\end{array}$ & $\begin{array}{l}\text { Increasing community } \\
\text { preparedness in facing } \\
\text { fires through the } \\
\text { formation of community } \\
\text { working groups, } \\
\text { environmental security } \\
\text { systems, training and the } \\
\text { use of mass media for } \\
\text { publication }\end{array}$ & $\begin{array}{l}\text { 1. Cooperating with } \\
\text { telecommunications } \\
\text { companies, so that the fire } \\
\text { emergency number is free of } \\
\text { charge and no disturbances } \\
\text { 2. Submit a special request to } \\
\text { the Government for the } \\
\text { protection policy of the Fire } \\
\text { and Safety Department } \\
\text { officers }\end{array}$ \\
\hline
\end{tabular}

Source: primary data (modified), 2019 
Based on the SWOT matrix in table 4, can be seen that an analysis of internal and external factors that support improving services at the Fire and Safety Department of Banda Aceh. So the alternative strategies can be developed to improve the level of services provided to the community and improve current mitigation efforts prepared by the department. The alternative strategies are compiled through the SWOT matrix. The results of the SWOT matrix analysis are 5 alternative service improvement strategies, namely as follows.

The SO strategy to improve services at the Fire and Safety Department of Banda Aceh City was arranged using the power to take advantage of opportunities.

1. Optimizing organizational planning and development by improving management, placing human resources in the right position and the effectiveness of using the right budget. So the programs that have been prepared by the department can be implemented well in terms of water supply, periodic maintenance of facilities such as hydrants that started to damage and fire extinguishers owned by the department and also a water supply facility.

The WO strategy to improve services at the Fire and Safety Department of Banda Aceh was prepared by minimizing weaknesses to take advantage of opportunities.

1. Increasing mitigation efforts by conducting periodic inspection programs on buildings and facilities and infrastructure that are available so that it will ready to be used any time and improving employee performances of the department with socialization programs to increase knowledge and skills in handling fire cases, as well as adding equipment in accordance with the development of knowledge that has been improved previously to face the advances in modern technology today.

The strategy of ST to improve services at the Fire and Safety Department of Banda Aceh City was compiled by utilizing the power to overcome threats.

1. Increasing community preparedness in facing fires through programs to form community working groups, environmental security systems, training and using of mass media for publications to improve community preparedness. Conducting fire education for communities, especially residents of dense settlements. Coordinating with peace officers and order with security officers. If the community has been resilient, surely when a fire disaster occurs, the community can anticipate the risks that will arise before waiting for the firefighters to arrive at the location.

WT's strategy to improve services at the Fire and Safety Department of Banda Aceh City was prepared by minimizing weaknesses to face threats.

1. Collaborating with telecommunication companies so that fire emergency number is free of charge and no disruption so that people can easily contact the department when a disaster occurs and during an emergency. Conducted a routine simulation program in collaboration with the POLRI (Indonesian National Police) and TNI (Indonesian National Armed Forces) to improve the preparedness and orderliness of employees and the community if a fire disaster occurs.

2. Submitting an application to the Government so that special legislation or qanun is made to the public that often disrupts Disdamkar officers when working on location such as taking over the duties of employees without being asked and do things that can harm the firefighters and the community themselves. Also, for the people who often do a fake phone call. This is very detrimental to the department in terms of operations, personnel, and 
others. Because until now, there has been no policy or punishment from the Government to the people who did it. If the policies and penalties have been set for the people who make such crimes, surely such problems will not happen again in the future.

\section{Conclusion}

1. Judging from the Firefighting Service Delivery System at the Fire and Safety Department of Banda Aceh, for the time being, is quite good. The administration system that is in accordance with the SOP, facilities, and infrastructure that have begun to be adequate in response, response and attitudes of the firefighters who are fast, responsive, kind and professional. It is just that there are a number of factors that have not been maximized such as the lack of regular maintenance of facilities owned.

2. From the SWOT analysis, four alternative strategies were obtained to improve the service of the Fire and Safety Department Banda Aceh that are (1) optimizing organizational planning and development by improving management, (2) Increasing mitigation efforts by conducting periodic maintenance on buildings, facilities and infrastructure owned (3) Increasing community preparedness through routine socialization programs, (4) Cooperating with telecommunications companies so that fire emergency numbers are free of charge and no disturbances, (5) Submit special requests to the Government for legal policies for protection of the firefighters.

\section{REFERENCES}

[1] Rachmat, Teknik praktis riset komunikasi. Malang: Prenada Media Group, 2009.

[2] M. Adelberty, "Analisis kualitas pelayanan dinas pemadam kebakaran kota Surabaya," J. Penelit. Adm. Publik, vol. 2, no. 1, pp. 216-223, 2016.

[3] P. Widayanto, "Analisis kinerja tim pemadam kebakaran dalam upaya penanggulangan kejadian kebakaran di dinas kebakaran kota Semarang," Universitas Negeri Semarang, 2016.

[4] S. Notoatmodjo, Metodologi penelitian administrasi. Jakarta: Rineka Cipta, 2012.

[5] C. G. Sevilla, Research methods. Quezon City, Metro Manila: Rex Bookstore, Inc, 1992.

[6] J. Vendri, "Analisis strategi peningkatan pelayanan dinas pemadam kebakaran provinsi DKI Jakarta," Institut Pertanian Bogor, 2006. 